\title{
XIX Canadian Congress of Neurological Sciences
}

\author{
Edmonton, Alberta \\ June 26 - 30, 1984
}

\section{Canadian Association for Child Neurology, Annual Meeting, June 26, 1984}

MORNING SYMPOSIUM:

\begin{tabular}{|c|c|}
\hline Welcome to the Old and New Glenrose & E.W. Gauk \\
\hline $\begin{array}{l}\text { The Glenrose Neonatal Follow-up Program } \\
\text { "1000 Little Soldiers" }\end{array}$ & C.M. Robertson \\
\hline $\begin{array}{l}\text { Effects of Maturation and Neurological Impairment } \\
\text { Evoked Potentials (Brain Stem Middle and Late) }\end{array}$ & P. Kileny \\
\hline Rehabilitation of Head Injured Children & J.M. Watt \\
\hline $\begin{array}{l}\text { The Use of Electrical Muscle Stimulation in } \\
\text { Treatment of Idiopathic Scoliosis }\end{array}$ & J. Raso \\
\hline Use of Endoscopy in Communication Disorders & F. Wilson \\
\hline
\end{tabular}

GUEST LECTURE:

Recent Developments in the Biochemistry of

Inherited Disorders of the Nervous System L. Wolfe

AFTERNOON SYMPOSIUM:

Progress in Supranuclear Palsy and Cerebromacular Degeneration

Chairman: F. Andermann

$\begin{array}{ll}\text { J. Wherrett } & \text { P. McLeod } \\ \text { J. Tibbles } & \text { E. Andermann } \\ \text { L. Wolfe } & \text { J.C. Jacob }\end{array}$

\section{Congress Educational Courses}

June 27, 1984

\section{Course 1 - Peripheral Neuropathies 1984: Advances and Approaches}

Chairmen: J. Stewart - Montreal

$$
\text { L. Heffernan - Halifax }
$$

Structure of Normal and Abnormal Nerve

G. Bray

The Assessment of the Patient with a Neuropathy:

1984 Approach

Function and Dysfunction of Healthy and Diseased Nerves

Acute Neuropathies:
a) Difficulties in diagnosis
b) Difficulties in management
c) Pathogenesis of Guillain-Barré: Update
d) Plasma exchange update

Diabetic Neuropathies
A. Asbury
W. Brown
J. Humphrey
J. Stewart
T. Feasby
J. Humphrey

A. Asbury 
Chronic Demyelinating Neuropathies:
a) Overview
G. Bray
b) Hereditary Types
G. Bray
c) Chronic Inflammatory Types
J. Humphrey
d) Type Associated with Paraproteinemia
T. Feasby
Discussion and Closing Remarks
A. Asbury

\section{Course 2 - Anatomical Review 1984}

Chairman: T. Myles
Anterior Circulation Aneurysms
A. Rhoton
Posterior Circulation Aneurysms
K. Sugita
Cerebello-pontine Angle
C. Tator
Spinal Cord and Nerve Roots
1. Turnbull
Brachial Plexus
A. Hudson

\section{Course 3 - Tumors of the Nervous System}

\section{Chairman: $P$. Muller}

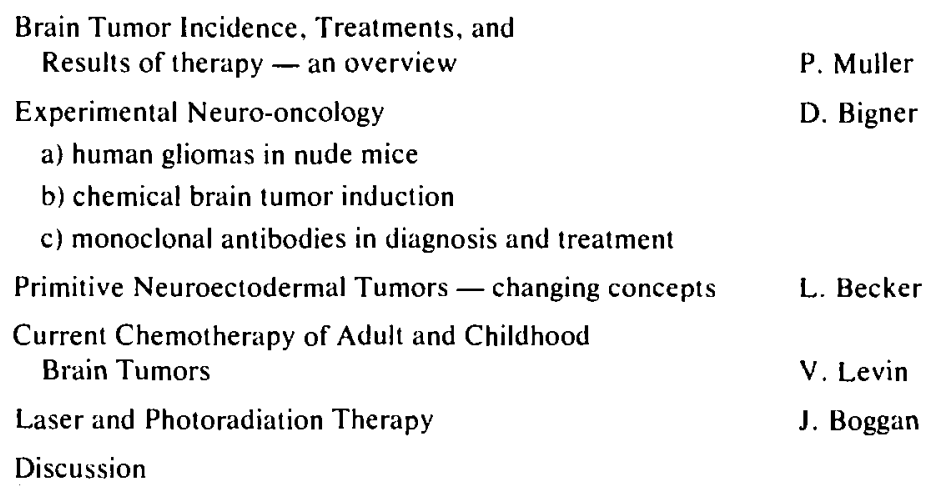

\section{SPECIAL LECTURES AND SYMPOSIA}

THURSDAY, JUNE 28, 1984

Presidential Address

The Impact of Head Trauma on Society - L. Ivan, Ottawa .

The Royal College Lecture

Trigeminal Nerve and Trigeminal Neuralgia - A. Rhoton, Gainesville, Florida

Heritage Lecture

Surgical Problems on Direct Approaches to A.V.M.'s - K. Sugita, Matsumoto, Japan

Canadian Neurological Society Guest Lecture

Experimental Studies in Brain Cardiovascular Control Systems - Implications in Hypertension and Cerebrovascular

Disorders - J. Conomy, Cleveland, Ohio

FRIDAY, JUNE 29, 1984

Canadian League Against Epilepsy Penfield Award Lecture

McKenzie Award Lecture

Spontaneous Intracerebral Hemorrhage: Analysis of Factors Affecting Prognosis - A. Dixon, Halifax

McNaughton Prize Lecture

Stroke Risk Determinants in Patients with Asymptomatic Cervical Bruits - B. R. Chambers, Toronto

Canadian Neurosurgical Society Penfield Lecture

Neurosurgical Applications of Brain Imaging - W. Feindel, Montreal 
SATURDAY. JUNE 30. 1984

Symposium A: Low Back Problems: Newer Management Techniques Chairman: A. Godon

Physiological Approaches to Pain

G. Lucier

Epidural Spinal Cord Stimulation

K. Kumar

Deep Brain Stimulation

P. Allen

Facet Joint Syndromes

P. Dupuis

A Pain Clinic Perspective

1. Clarke

Panel Discussion - The "Failed Back"

Symposium B: Dementias and Alzheimer's Disease

Chairman: P. McGeer

Positron Emission Tomography in Alzheimer's Disease

D. Comar

Combined Positron Emission Tomography and Nuclear Magnetic Resonance Studies in Dementias

P. McGeer

Tangles, Plaques and the Basal Forebrain: A Critical Evaluation of Histopathology in Alzheimer's Disease

N. Ball

Altered Chromatin Structure in Alzheimer's Disease

D. Crapper-McLachlan

Relative Importance of Acetylcholine Neurons in Alzheimer's Disease

P. Etienne

Neuropathology and Biochemistry of Alzheimer's Disease

H.M. Wisniewski

Panel Discussion - Future Approaches to the Problems of Dementias 